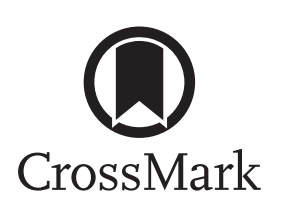

\section{Mycobacterium tuberculosis transmission from patients with drug-resistant compared to drug-susceptible TB: a systematic review and meta-analysis}

To the Editor:

The extent to which drug-resistant (DR) Mycobacterium tuberculosis strains cause infection and progression to tuberculosis (TB) disease in comparison to drug-susceptible (DS) strains is unknown. Studies in guinea pigs and in vitro experiments have suggested a reduced fitness of organisms that harbour mutations that confer drug resistance $[1,2]$; it was therefore believed that transmitted drug resistance was a rare event. However, more recent work using molecular typing has shown transmission events occurring in the context of DR-TB [3]. Understanding the risk of transmission, infection and progression to disease in the context of DR-TB is important to guide control measures and help predict the evolution and magnitude of the multidrug-resistant (MDR)-TB epidemic. Hence, we performed a systematic review and meta-analysis to assess whether M. tuberculosis transmission and progression to TB disease (risk/rate of M. tuberculosis infection in all contacts, risk/rate of TB disease in all contacts and risk/rate of TB disease in infected contacts) differ between DR- and DS-TB.

Nine databases were searched. Eligible studies compared contacts of index cases with DS- and DR-TB and reported on risk of $M$. tuberculosis infection (determined either by the interferon gamma release assay (IGRA) or tuberculin skin test (TST)) or risk, or rate of TB disease and risk/rate of TB disease in infected (positive TST or IGRA) contacts. Fixed and random effects meta-analyses were used to obtain pooled estimates with $95 \%$ confidence intervals (95\% CI) where possible. Results were stratified by resistance pattern of the isolate causing disease in the index patients, differentiating between DS, mono-resistant and MDR cases. Where data were not presented in the publication, first authors were contacted to obtain additional information. The quality of studies was assessed using an adapted Newcastle Ottawa Scale for cohort studies.

A total of 5316 citations were identified; 1962 duplicates were removed. Of those remaining, 3063 were considered not relevant and excluded. Of the 291 articles retained for full-text review, seven were included [4-10]. Characteristics of the index patients and their contacts are presented in table 1 . The included studies enrolled participants during the years 1975 to 2013 and were conducted in six countries: Argentina $(n=1)$ [7], Brazil $(n=2)[4,5]$, Peru $(n=1)$ [6], Canada $(n=1)$ [8], Mexico $(n=1)$ [9] and the United States $(n=1)$ [10]. No studies from Africa, Asia or Europe were identified. Two studies were conducted in a country classified as high TB-burden (Brazil) [4,5] and one from a high MDR-TB-burden country (Peru) [6].

Two studies [5,6] were marked as good quality; the other five were of moderate quality because of a high risk of selection bias due to loss to follow-up. All studies investigating TB disease as an outcome were considered at high risk for ascertainment bias. Furthermore, drug susceptibility testing (DST) was not performed on all secondary isolates. No study confirmed transmission through genotyping.

The M. tuberculosis infection was the outcome in five studies [5, 7-10]. The pooled relative risk of M. tuberculosis infection defined by positive TST using a fixed or random effects model was 1.24 (95\% CI 1.08-1.42 fixed, 95\% CI 0.98-1.44 random) comparing contacts of index cases with MDR-TB and DS-TB. Heterogeneity was high with an $\mathrm{I}^{2}$ of $75 \%$.

@ERSpublications

No evidence that drug-resistant TB results in fewer infections or cases in contacts than drugsusceptible TB http://ow.ly/dgez30f87dr

Cite this article as: Kodama C, Lange B, Olaru ID, et al. Mycobacterium tuberculosis transmission from patients with drug-resistant compared to drug-susceptible TB: a systematic review and meta-analysis. Eur Respir J 2017; 50: 1701044 [https://doi.org/10.1183/13993003.01044-2017]. 


\begin{tabular}{|c|c|c|c|c|c|c|c|c|c|c|c|c|c|c|c|c|c|c|}
\hline $\begin{array}{l}\text { First author } \\
\text { [ref.] }\end{array}$ & Country & $\begin{array}{c}\text { Study period and } \\
\text { type }\end{array}$ & $\begin{array}{l}\text { DR/ } \\
\text { DS }\end{array}$ & $\begin{array}{c}\text { Method of } \\
\text { patient } \\
\text { selection }\end{array}$ & $\begin{array}{c}\text { Index } \\
\text { patients } \\
\text { n }\end{array}$ & $\begin{array}{c}\text { Age } \\
\text { years } \\
\text { mean } \\
\text { tso }\end{array}$ & $\begin{array}{l}\text { sex } \\
\text { F/M } \\
\%\end{array}$ & $\underset{\text { status }}{\text { HIV }}$ & DR pattern n $1 \%$ ) & $\begin{array}{c}\text { Contacts n } \\
\text { (mean) }\end{array}$ & $\begin{array}{l}\text { Outcome } \\
\text { measures for } \\
\text { M. tuberculosis } \\
\text { infection }\end{array}$ & $\begin{array}{l}\text { TB infection events } \mathrm{n} / \\
\mathrm{N} \text { (\%) }\end{array}$ & $\begin{array}{l}\text { Latent TB } \\
\text { therapy }\end{array}$ & $\begin{array}{c}\text { TB disease events } n / \\
\text { N (\%) }\end{array}$ & $\begin{array}{l}\text { Timing of } \\
\text { diagnosis }\end{array}$ & $\begin{array}{l}\text { Risk of infection } \\
\text { RR }(95 \% \text { CII) }\end{array}$ & $\begin{array}{l}\text { Risk of disease } \\
\text { RR }(95 \% \mathrm{Cll})^{*}\end{array}$ & Overall risk of bias \\
\hline \multirow[t]{2}{*}{ SWMOER [10] } & \multirow[t]{2}{*}{ USA } & \multirow[t]{2}{*}{$\begin{array}{l}\text { 1975-1977, cohort } \\
\text { (prospectivel, NR } \\
\text { (study period } \\
32 \text { months) }\end{array}$} & DR & $\begin{array}{l}\text { Recruited from } \\
\text { CDC laboratory }\end{array}$ & 398 & NR & NR & NR & $\begin{array}{l}\text { INH-resistant: } 178(144.5) ; \\
\text { SM-resistant: } 136(43.0) ; \\
\text { INH/SM-resitant: } 86 \\
\text { [21.5] }\end{array}$ & $\begin{array}{l}\text { Paediatric } \\
\text { contacts: } \\
627(1.6)\end{array}$ & $\begin{array}{l}\text { TST } \geqslant 5 \mathrm{~mm} \text { (12 } \\
\text { clinics), TST } \\
\geqslant 10 \mathrm{~mm}(3 \\
\text { clinics), ] } \\
\text { unknown } 12 \\
\text { clinics) }\end{array}$ & DR: $239 / 601139.81$ & NR & $\begin{array}{l}\text { DR: } 4 / 601 \text { 10.6 of total, } \\
1.7 \text { of infected) }\end{array}$ & NR & \multirow[t]{2}{*}{$\begin{array}{c}\text { DR-non-MDR } \\
\text { versus DS: } 1.19 \\
(1.03-1.36)\end{array}$} & $\begin{array}{c}\text { DR-non-MDR } \\
\text { versus DS: } 0.84 \\
{[0.24-2.94]}\end{array}$ & \multirow[t]{2}{*}{$\begin{array}{c}\text { High-moderate } \\
\text { Iselection bias } \\
\text { likely, comparability } \\
\text { and outcome } \\
\text { ascertainment } \\
\text { likely) }\end{array}$} \\
\hline & & & DS & $\begin{array}{l}\text { Matched to } \\
\text { study patients } \\
\text { for age, race, } \\
\text { sex and } \\
\text { location }\end{array}$ & 398 & NR & NR & NR & Fully susceptible & 778 (2.0) & $\begin{array}{l}\text { TST } \geqslant 5 \mathrm{~mm}(12 \\
\text { clinics), TST } \\
\geqslant 10 \mathrm{~mm}(3 \\
\text { clinics), } \\
\text { unknown } 12 \\
\text { clinics) }\end{array}$ & DS: 252/751 (33.6) & NR & $\begin{array}{l}\text { DS: } 6 / 7753 \text { (10.8 of total, } \\
2.4 \text { of infectedl) }\end{array}$ & NR & & & \\
\hline \multirow[t]{2}{*}{ Bareoso [4] } & \multirow[t]{2}{*}{ Brazil } & \multirow[t]{2}{*}{$\begin{array}{l}\text { 1990-1999, cohort } \\
\text { (retrospectivel, } 2 \\
\quad \text { years }\end{array}$} & $\mathrm{DR}$ & $\begin{array}{l}\text { Basad on the } \\
\text { results of hST } \\
\text { at medical } \\
\text { facilities }\end{array}$ & 126 & $39 \pm 25$ & $\begin{array}{l}37.31 \\
62.7\end{array}$ & $\begin{array}{l}78 \text { of } 126 \\
\text { tested, all } \\
\text { results } \\
\text { negative }\end{array}$ & MOR & $557(14.4)$ & NR & NR & NR & MDR: $25 / 5577(4.5)$ & NR & \multirow[t]{2}{*}{ NR } & $\begin{array}{l}\text { MDR versus DS: } \\
0.84 \text { (0.52-1.37) }\end{array}$ & \multirow{2}{*}{$\begin{array}{l}\text { Low-moderate } \\
\text { Iselection bias } \\
\text { likely, commarability } \\
\text { and outcome } \\
\text { ascertainment } \\
\text { likely) }\end{array}$} \\
\hline & & & DS & $\begin{array}{l}\text { Matched to } \\
\text { study patients } \\
\text { for sex, age, } \\
\text { and year of first } \\
\text { treatment }\end{array}$ & 176 & $41 \pm 14$ & $\begin{array}{l}37.51 \\
62.5\end{array}$ & $\begin{array}{l}97 \text { of } 176 \\
\text { tested, all } \\
\text { results } \\
\text { negative }\end{array}$ & Fully susceptible & $752\{4.3\}$ & NR & NR & NR & DS: 41/752 (5.5) & NR & & & \\
\hline \multirow[t]{3}{*}{ Jonusron [8] } & \multirow[t]{3}{*}{ Canada } & \multirow[t]{3}{*}{$\begin{array}{l}\text { 1990-2008, cohort } \\
\text { [retrospectivel, 123 } \\
\text { [IRR 19-239] } \\
\text { months }\end{array}$} & DR & $\begin{array}{l}\text { Recruited from } \\
\text { national TB } \\
\text { registry }\end{array}$ & 124 & NR & $\mathrm{NR}$ & NR & $\begin{array}{l}\text { INH-mono- resistant } \\
\text { (HMR): } 96\end{array}$ & $\begin{array}{c}\text { HMR: } 249 \\
{[3.0]}\end{array}$ & & $\begin{array}{l}\text { Non-MDR (IMMR)": } 121 / \\
249(449)\end{array}$ & & $\begin{array}{l}\text { Non-MDR (HMR): } 8 / \\
249 \text { (3.0) }\end{array}$ & & $\begin{array}{c}\text { DR-non-MOR } \\
\text { versus DS: } 1.1 .53 \\
(1.34-1.75)\end{array}$ & $\begin{array}{l}\text { DR-non-MDR } \\
\text { versus SS: 1.43 } \\
\text { [0.71-2.87] }\end{array}$ & \multirow{3}{*}{$\begin{array}{c}\text { Low-moderate } \\
\text { Iselection bias } \\
\text { likely, comparability } \\
\text { and outcome } \\
\text { ascertianment } \\
\text { likely) }\end{array}$} \\
\hline & & & & & & & & & $\begin{array}{l}\text { INH/RMP-resistant: } 28 \\
\text { (MMOR) }\end{array}$ & $\begin{array}{l}\text { MDR: } 89 \\
{[3.0]}\end{array}$ & $\begin{array}{l}\text { TST } \geqslant 5 \mathrm{~mm} \\
{[3 \text { months to }} \\
<1 \text { year after } \\
\text { source } \\
\text { diagnosis }]\end{array}$ & MDR: 42/89 447$\rangle$ & $\begin{array}{l}12 / 89 \\
\text { treated }\end{array}$ & $\begin{array}{l}\text { MDR: } 5 / 89 \text { 16.0|, all } \\
\text { susceptible }\end{array}$ & $\begin{array}{l}\text { All diagnosed } \\
\text { within } \\
3 \text { months of } \\
\text { index patients }\end{array}$ & $\begin{array}{l}\text { MDR versus DS: } \\
1.49 \text { (1.19-1. 1.86) }\end{array}$ & $\begin{array}{l}\text { MDR versus DS: } \\
2.5(1.05-5.93)\end{array}$ & \\
\hline & & & DS & $\begin{array}{l}\text { Recruited from } \\
\text { national TB } \\
\text { registry }\end{array}$ & 2895 & $\mathrm{NR}$ & & & Fully susceptible & $73099(3.0)$ & $\begin{array}{l}\text { TST } \geqslant 5 \mathrm{~mm} \\
{[3 \text { months to }} \\
<1 \text { year after } \\
\text { source } \\
\text { diagnosis }]\end{array}$ & DS: $2321 / 7309$ (32) & NR & DS: $168 / 74772[2.0]$ & NR & & & \\
\hline \multirow[t]{2}{*}{ Texerera [5] } & \multirow[t]{2}{*}{ Brazil } & \multirow[t]{2}{*}{$\begin{array}{l}\text { 1994-1998, cohort } \\
\text { (prospective) NR } \\
\text { (Istudy period } \\
54 \text { months) }\end{array}$} & DR & $\begin{array}{l}\text { Recruited from } \\
\text { TB referral } \\
\text { centre }\end{array}$ & 26 & $\begin{array}{l}39.5 \\
\pm 12\end{array}$ & $\begin{array}{l}23 / \\
77\end{array}$ & $\begin{array}{l}\mathrm{HIV+}+5 \\
(120 \%) \\
\mathrm{HIV}-21 \\
180 \%)\end{array}$ & 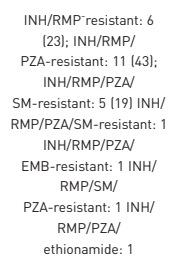 & $157(6.0)$ & $\mathrm{TST} \geqslant 10 \mathrm{~mm}$ & $\begin{array}{l}\text { MDR: } 59 / 133(\mid 44) \text {, no } \\
\text { therapy }\end{array}$ & & MDR 6/157 74.01 & $\begin{array}{l}3 \text { a median } \\
10 \text { lrange }- \\
\text { 34l months } \\
\text { atfer intital } \\
\text { evaluation. }\end{array}$ & $\begin{array}{l}\text { MDR versus DS: } \\
1.19 \text { [0.92-1.54) }\end{array}$ & $\begin{array}{l}\text { MDR versus DS: } \\
0.7 \text { [0.19-2.59) }\end{array}$ & \multirow[t]{2}{*}{$\begin{array}{l}\text { Good (comparability } \\
\text { and outcome } \\
\text { ascertainment } \\
\text { likely) }\end{array}$} \\
\hline & & & DS & $\begin{array}{l}\text { Two DS index } \\
\text { patients were } \\
\text { matched to } \\
\text { each new } \\
\text { MDR-TB patient }\end{array}$ & 52 & $\begin{array}{l}38.4 \\
\pm 13\end{array}$ & $\begin{array}{l}23 / \\
77\end{array}$ & 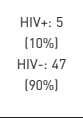 & Fully susceptible & $251(5.0)$ & $\mathrm{TST} \geqslant 10 \mathrm{~mm}$ & DS: $86 / 231$ (37) & NR & DS: $11 / 251$ | 14.01 & $\begin{array}{l}\text { Median 10 } \\
\text { Irange 2-34) } \\
\text { months atter } \\
\text { initial } \\
\text { evaluation }\end{array}$ & & & \\
\hline
\end{tabular}




\begin{tabular}{|c|c|c|c|c|c|c|c|c|c|c|c|c|c|c|c|c|c|c|}
\hline $\begin{array}{l}\text { First author } \\
\text { [ref.] }\end{array}$ & Country & $\begin{array}{c}\text { Study period and } \\
\text { type }\end{array}$ & $\begin{array}{l}\text { DR/ } \\
\text { DS }\end{array}$ & $\begin{array}{c}\text { Method of } \\
\text { patient } \\
\text { selection }\end{array}$ & $\begin{array}{c}\text { Index } \\
\text { patients } \\
n\end{array}$ & $\begin{array}{c}\text { Age } \\
\text { years } \\
\text { mean } \\
\text { Iso }\end{array}$ & $\begin{array}{l}\text { Sex } \\
\text { F/M } \\
\%\end{array}$ & $\underset{\text { status }}{\text { HIV }}$ & DR pattern n $(\%)$ & $\begin{array}{c}\text { Contacts n } \\
\text { (mean) }\end{array}$ & $\begin{array}{c}\text { Outcome } \\
\text { measures tor } \\
\text { M. tuberculosis } \\
\text { infection }\end{array}$ & $\begin{array}{c}\text { TB infection events n/ } \\
N(\%)\end{array}$ & $\begin{array}{l}\text { Latent TB } \\
\text { therapy }\end{array}$ & $\begin{array}{l}\text { TB disease events } n / \\
\mathrm{N}(\%)\end{array}$ & $\begin{array}{l}\text { Timing of } \\
\text { diannosis }\end{array}$ & $\begin{array}{l}\text { Risk of infection } \\
\text { RR }(95 \% \text { CII) }\end{array}$ & $\begin{array}{l}\text { Risk of disease } \\
\text { RR (95\% Cl1 })^{*}\end{array}$ & Overall risk of bias \\
\hline \multirow[t]{2}{*}{ PalMero [7] } & \multirow[t]{2}{*}{ Argentina } & \multirow[t]{2}{*}{$\begin{array}{l}\text { 1998-2000, cohort } \\
\text { (retrospectivel, } 3 \\
\text { years }\end{array}$} & $\mathrm{DR}$ & $\begin{array}{l}\text { Recruited from } \\
\text { TB registry }\end{array}$ & 37 & $\begin{array}{l}31.3 \\
\pm 9.3\end{array}$ & $\begin{array}{l}33 / \\
68\end{array}$ & $\begin{array}{l}\text { HIVt: } 21 \\
{[57 \%]} \\
H I V-16 \\
{[43 \%]}\end{array}$ & MOR & $97(2.6)$ & $\mathrm{TST} \geqslant 10 \mathrm{~mm}$ & MDR: 17/97 (17.5) & NR & MDR: $2 / 97(2.1)$ & NR & \multirow[t]{2}{*}{$\begin{array}{l}\text { MDR versus DS: } \\
1.45(0.87-2.43)\end{array}$} & \multirow[t]{2}{*}{$\begin{array}{l}\text { MDR versus DS: } \\
0.92(0.2-4.25)\end{array}$} & $\begin{array}{c}\text { Low-moderate } \\
\text { SLelection nias } \\
\text { likely, comporabability } \\
\text { and outcome } \\
\text { ascertainment }\end{array}$ \\
\hline & & & DS & $\begin{array}{l}\text { Recruited from } \\
\text { TB registry }\end{array}$ & 100 & $\begin{array}{l}29.6 \\
\pm 8.6\end{array}$ & $\begin{array}{l}241 \\
76\end{array}$ & $\begin{array}{l}\text { HIV+: } 38 \\
{[38 \%]} \\
\text { HIV:- } 62 \\
{[62 \%]}\end{array}$ & Fully susceptible & $356(3.5)$ & $\mathrm{TST} \geqslant 10 \mathrm{~mm}$ & DS: 43/356 12.11 & NR & DS: $8 / 356(2.2 \%)$ & NR & & & [ikelyy) \\
\hline \multirow[t]{2}{*}{ GrendJEan [6] } & \multirow[t]{2}{*}{ Peru } & $\begin{array}{l}\text { 2010-2013, cohort } \\
\text { (prospectivel, oR } \\
1425 \text { person years } \\
\text { (mean } 494 \text { days) }\end{array}$ & DR & $\begin{array}{l}\text { Recruited at } \\
\text { diagnosis from } \\
\text { reference } \\
\text { laboratories }\end{array}$ & 213 & 32 & $\begin{array}{l}611 \\
39\end{array}$ & $\begin{array}{l}\text { HIVt: } 18 \\
\text { I8\%) } \\
\text { HIV-: } 195 \\
192 \%]\end{array}$ & MDR & $1055(4.0)$ & NR & NR & $12.5 \%$ & $\begin{array}{l}\text { MDR: } 35 / 1055 \text { (3.3\%), } \\
28 \text { ST Terformed of } \\
\text { which } 24 \text { MDR and } 4 \\
\text { DS }\end{array}$ & $\begin{array}{l}\text { Day 1 of } \\
\text { follow-up to } \\
\text { day } 600 \text { of } \\
\text { follow-up }\end{array}$ & \multirow[t]{2}{*}{ NR } & \multirow[t]{2}{*}{$\begin{array}{l}\text { MDR versus DS: } \\
0.71 \text { 10.49-1.031 }\end{array}$} & $\begin{array}{l}\text { Good loutcome } \\
\text { ascertainment } \\
\text { likely) }\end{array}$ \\
\hline & & $\begin{array}{l}2010-2013 \text { cohort } \\
\text { (prospectivel, DS } \\
2620 \text { person years } \\
\text { (mean } 406 \text { days) }\end{array}$ & DS & $\begin{array}{l}\text { Matched to } \\
\text { study patients } \\
\text { for age, race, } \\
\text { sex and } \\
\text { geographic } \\
\text { location }\end{array}$ & 487 & 33 & $\begin{array}{l}61 / \\
39\end{array}$ & $\begin{array}{l}\text { HIIV+ } 20 \\
{[4 \%)} \\
H I V-: 467 \\
{[96 \%]}\end{array}$ & Fully susceptible & $2362(4.0)$ & NR & NR & $17.2 \%$ & DS: $114 / 24441 \mid 4.8 \%$ l & $\begin{array}{l}\text { Day } 1 \text { of } \\
\text { follow-up to } \\
\text { day } 600 \text { of } \\
\text { follow-up }\end{array}$ & & & \\
\hline \multirow[t]{2}{*}{$\begin{array}{l}\text { Lanuloo-LLasean } \\
{[9]}\end{array}$} & Mexico & $\begin{array}{l}2011-2013, \\
\text { cross-sectional, no } \\
\text { follow-up }\end{array}$ & DR & $\begin{array}{l}\text { Recruited from } \\
\text { TB clinic based } \\
\text { on culture and } \\
\text { DST performed } \\
\text { at the clinic }\end{array}$ & $\begin{array}{l}33(20 \\
M D R)^{n}\end{array}$ & NR & & & NR & $\begin{array}{l}\text { MDR: 96/41 } \\
\text { I. } 40.1 . \\
\text { paediatric } \\
\text { contacts }\end{array}$ & $\begin{array}{l}\text { TST } \geqslant 5 \mathrm{~mm}, \\
\text { IGRA } \\
\geqslant 0.35 \mathrm{UU} \cdot \mathrm{m}^{-1}\end{array}$ & 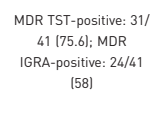 & Not treated & NR & & \multirow[t]{2}{*}{$\begin{array}{l}\text { MDR versus DS } \\
\text { (IST): } 0.910 .70 .74- \\
1.111)\end{array}$} & \multirow[t]{2}{*}{ NR } & $\begin{array}{l}\text { Low-moderate } \\
\text { Iselection bias } \\
\text { likely, comparability } \\
\text { and outcome } \\
\text { ascertainment } \\
\text { likely) }\end{array}$ \\
\hline & & & DS & $\begin{array}{l}\text { Recruited from } \\
\text { TB clinic based } \\
\text { on culture and } \\
\text { DST performed } \\
\text { at the clinic }\end{array}$ & 37 & $\mathrm{NR}$ & & & NR & $77(2.3)$ & $\begin{array}{l}\text { TST } \geqslant 5 \mathrm{~mm}, \\
\text { IGRA } \\
\geqslant 0.35 \mathrm{U} \cdot \mathrm{m}^{-1}\end{array}$ & $\begin{array}{l}\text { DS TST-positive: 64/77 } \\
\text { |833| DS IGRA-positive: } \\
\text { 32/777 | | } 24 \mid\end{array}$ & $\begin{array}{l}\text { Treated with } \\
\text { INH or RMP. } \\
\text { unclear } \\
\text { proportion }\end{array}$ & NR & & & & \\
\hline Meta-analysis & & & & & & & & & & & & 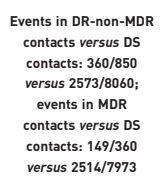 & & 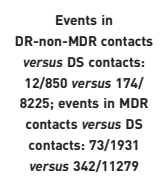 & & $\begin{array}{c}\text { DR-non-MDR } \\
\text { versus DS: 1.33 } \\
\text { (11.2-1.46); MDR } \\
\text { versus DS: 1.24 } \\
(1.08-1.42)\end{array}$ & $\begin{array}{c}\text { DR-non-MDR } \\
\text { versus DS: } 1.23 \\
\text { (0.67-2.27); MDR } \\
\text { versus DS: } 0.81 \\
(0.64-1.06)\end{array}$ & \\
\hline
\end{tabular}

DR: drug-resistant; DS: drug-susceptible; F: female; M: male; M. tuberculosis: Mycobacterium tuberculosis; TB: tuberculosis; NR: not recorded; CDC: Centers for Disease Control and Prevention; INH: isonicotinylhydrazide (isoniazid); SM: streptomycin; TST: tuberculin skin test; MDR: multidrug-resistant; DR-non-MDR: other resistance or not specified, not INH/ rifampicin (RMP); DST: drug-susceptibility testing; IQR: interquartile range; HMR: isoniazid mono-resistant; PZA: pyrazinamide; EMB: ethambutol; IGRA: interferon- $\gamma$ release assay.

\#: fixed effects meta-analysis; " 
Six studies $[4-8,10]$ reported the rate or risk of TB disease among contacts of DR-TB and DS-TB index patients after diagnosis of the index patient. The mean duration of follow-up ranged from 406 days [6] to 123 months [8]. Five studies provided data for a meta-analysis, showing no evidence of a reduced risk of active TB in contacts of MDR-TB index cases (Relative risk ratio $0.81,95 \%$ CI $0.64-1.06, \mathrm{I}^{2}=43 \%$ ) or DR-TB including non-MDR-TB index cases only (Relative risk ratio $1.23,95 \%$ CI $0.67-2.27$ ). Calculation of pooled rate ratios was precluded as person-years of follow-up was not provided by all studies.

Incidence of TB disease among contacts already infected (positive TST) at time of first assessment was analysed by one study in young children with high exposure, without reporting information on chemoprophylaxis [10]. Over a total study period of 32 months, $1.7 \%$ of the infected contacts of DR-TB index patients and $2.4 \%$ of DS-TB index patients progressed to TB disease $(\mathrm{p}=0.41)$.

We believe this review offers important comparative information on the transmissibility of DR-TB. Overall, our meta-analysis demonstrates a greater likelihood of M. tuberculosis infection in contacts of DR-TB index patients. However, any estimate of transmissibility will be a compound effect of the strain and other factors influencing the risk of the contact becoming infected, such as infectiousness of the index case, and duration and intensity of the exposure. Contacts of DR-TB index cases are more likely to have been exposed for a longer duration on multiple occasions and possibly exposed to more infectious and poorly treated TB. This might explain the higher risk of $M$. tuberculosis infection among contacts of DR-TB index patients.

On the other hand, our meta-analysis did not find evidence of a reduced risk of TB disease among contacts of DR-TB compared to DS-TB index cases. However, data on the risk of active TB is more difficult to interpret, owing to a limited follow-up time in most studies.

This review has several limitations and highlights research gaps both geographically and with regards to risk groups. Few studies were identified comparing contacts of DR-TB and DS-TB index patients. Some studies, summarised in other systematic reviews, had to be excluded as they lacked contacts of both DR- and DS-TB index patients [11, 12], or susceptibility testing [13]. The generalisability of this review is geographically limited, as the studies included were all from the Americas. The lack of studies from high MDR-TB burden countries in Central Asia and high HIV-prevalence settings, such as sub-Saharan Africa, is both surprising and of concern. Only two studies involved paediatric contacts $[9,10]$ and none focused on people living with HIV. A previous prospective study without a drug-susceptible comparison group has shown a high risk of $M$. tuberculosis infection and progression to disease in paediatric contacts of adult index patients with MDR tuberculosis [14]. Studies using child contacts minimise misclassification, as children are less likely to have been infected by additional TB cases from outside the household than adults are.

The quality of studies was moderate, owing to the risk of selection and ascertainment bias. Measurement of loss to follow-up and follow-up periods varied between studies, and the pooled, as well as the individual study results could well be biased by differential loss to follow-up in contacts of DR- and DS-TB index patients. Outcome ascertainment for secondary TB and length of follow-up differed across studies, which might explain the heterogeneity of results. Comparison between studies was further challenged by differences in analysis. Some studies used incidence, whereas others used cumulative prevalence as the outcome measure. In addition, few studies adjusted for potential confounders, such as socio-economic differences, smoking or duration of contact.

Whereas heterogeneity and limitations indicate a need for caution in interpreting these findings, the suggestion of increased transmission risk from DR-TB patients does not support the previously held dogma that DR-TB is less transmissible than DS-TB. This is critical when predicting the evolution of the MDR-TB epidemic and the likely impact of measures, such as prompt diagnosis, treatment of active and latent TB and infection control. For clinicians and national tuberculosis programmes, these findings underscore the importance of infection control and contact tracing in the context of MDR-TB. The relative fitness of MDR-TB compared to DS-TB strains is the key modelling parameter for predicting the future MDR-TB epidemic [15]. Quantifying transmissibility and progression to TB disease in the context of dug resistance is paramount to ensure validity of predictions, as TB control policy becomes increasingly reliant on modelled estimates of $M$. tuberculosis infection and TB disease.

Chiori Kodama ${ }^{1,11}$, Berit Lange ${ }^{2,3,11}$, Ioana D. Olaru $\oplus^{4}$, Palwasha Khan ${ }^{1}$, Marc Lipman ${ }^{5}$, James A. Seddon ${ }^{6}$, Derek Sloan $^{7}$, Louis Grandjean ${ }^{1}$, Rashida Abbas Ferrand ${ }^{8,9}$ and Katharina Kranzer,10

${ }^{1}$ Dept of Infectious Disease Epidemiology, London School of Hygiene and Tropical Medicine, London, UK. ${ }^{2}$ Division of Infectious Diseases, Dept of Medicine II, Medical Center - Faculty of Medicine, University of Freiburg, Freiburg, Germany. ${ }^{3}$ Centre for Chronic Immunodeficiency, Medical Center - Faculty of Medicine, University of Freiburg, Freiburg, Germany. ${ }^{4}$ Division of Clinical Infectious Diseases, Research Center Borstel, Borstel, Germany. ${ }^{5}$ Royal Free London NHS Foundation Trust and UCL Respiratory, Division of Medicine, University College London, London, UK. 
${ }^{6}$ Centre for International Child Health, Dept of Paediatrics, Imperial College London, London, UK. ${ }^{7}$ School of Medicine, University of St Andrews, Fife, UK. ${ }^{8}$ Dept of Clinical Research, London School of Hygiene and Tropical Medicine, London, UK. ${ }^{9}$ Biomedical Research and Training Institute, Harare, Zimbabwe. ${ }^{10}$ National and Supranational Reference Laboratory, Leibnitz Research Centre, Borstel, Germany. ${ }^{11}$ These authors contributed equally.

Correspondence: Berit Lange, Division of Infectious Diseases, Dept of Medicine II, Medical Center, Hugstetterstr. 55, 79106 Freiburg, Germany. E-mail: Berit.Lange@uniklinik-freiburg.de

Received: Jan 192017 | Accepted after revision: Aug 032017

Support statement: Institutional funding for B. Lange was supported by the German Federal Ministry of Education and Research (BMBF 01EO1303 grant to the Center for Chronic Immunodeficiency). P. Khan is funded by a Wellcome Trust clinical research training fellowship (grant number 100137/Z/12/Z). Funding information for this article has been deposited with the Crossref Funder Registry.

Conflict of interest: None declared.

Acknowledgements: We would like to acknowledge the valuable administrative support during the conduct of this study by Johannes Camp and Lucy Wong of University Hospital Freiburg.

Contributions of authors: K. Kranzer conceived the idea for the systematic review. K. Kranzer, C. Kodama and B. Lange designed the study. K. Kranzer, C. Kodama and B. Lange performed screening and data extraction. C. Kodama and B. Lange assessed risk of bias. B. Lange and K. Kranzer performed the meta-analysis. I. Olaru, P. Khan, M. Lipman, J. Seddon, D. Sloan, L. Grandjean and R. Ferrand contributed to the analysis and manuscript writing. All authors read and approved the final version of the manuscript.

\section{References}

1 Mitchison DA. The virulence of tubercle bacilli from patients with pulmonary tuberculosis in India and other countries. Bull Int Union Tuberc 1964; 35: 287-306.

2 Gagneux S. Fitness cost of drug resistance in Mycobacterium tuberculosis. Clin Microbiol Infect 2009; 15: 66-68.

3 Meftahi N, Namouchi A, Mhenni B, et al. Evidence for the critical role of a secondary site rpoB mutation in the compensatory evolution and successful transmission of an MDR tuberculosis outbreak strain. J Antimicrob Chemother 2016; 71: 324-332.

4 Barroso EC, Mota RMS, Pinheiro VGF, et al. Ocorrência de tuberculose doença entre contatos de tuberculose sensível e multirresistente. Jornal Brasileiro de Pneumologia 2004; 30: 311-318.

5 Teixeira L, Perkins MD, Johnson JL, et al. Infection and disease among household contacts of patients with multidrug-resistant tuberculosis. Int J Tuberc Lung Dis 2001; 5: 321-328.

6 Grandjean L, Gilman RH, Martin L, et al. Transmission of multidrug-resistant and drug-susceptible tuberculosis within households: a prospective cohort study. PLoS Med 2015; 12: e1001843.

7 Palmero D, Cusmano L, Bucci Z, et al. Infectiousness and virulence of multidrug-resistant and drug susceptible tuberculosis in adult contacts. Medicina (B Aires) 2002; 62: 221-225.

8 Johnston J, Admon A, Ibrahim A, et al. Long term follow-up of drug resistant and drug susceptible tuberculosis contacts in a low incidence setting. BMC Infect Dis 2012; 12: 266.

9 Laniado-Laborin R, Cazares-Adame R, Volker-Soberanes ML, et al. Latent tuberculous infection prevalence among paediatric contacts of drug-resistant and drug-susceptible cases. Int J Tuberc Lung Dis 2014; 18: 515-519.

10 Snider DE Jr, Kelly GD, Cauthen GM, et al. Infection and disease among contacts of tuberculosis cases with drug-resistant and drug-susceptible bacilli. Am Rev Respir Dis 1985; 132: 125-132.

11 Fox GJ, Barry SE, Britton WJ, et al. Contact investigation for tuberculosis: a systematic review and meta-analysis. Eur Respir J 2013; 41: 140-156.

12 Shah NS, Yuen CM, Heo M, et al. Yield of contact investigations in households of patients with drug-resistant tuberculosis: systematic review and meta-analysis. Clin Infect Dis 2014; 58: 381-391.

13 Fox GJ, Anh NT, Nhung NV, et al. Latent tuberculous infection in household contacts of multidrug-resistant and newly diagnosed tuberculosis. Int J Tuberc Lung Dis 2017; 21: 297-302.

14 Schaaf HS, Gie RP, Kennedy M, et al. Evaluation of young children in contact with adult multidrug-resistant pulmonary tuberculosis: a 30-month follow-up. Pediatrics 2002; 109: 765-771.

15 Knight GM, Colijn C, Shrestha S, et al. The distribution of fitness costs of resistance-conferring mutations is a key determinant for the future burden of drug-resistant tuberculosis: a model-based analysis. Clin Infect Dis 2015; 61: Suppl. 3, S147-S154. 